\title{
Na,K-ATPase: Comparison of the Cellular Localization of $\alpha$-Subunit mRNA and Polypeptide in Mouse Cerebellum, Retina, and Kidney
}

\author{
V. Hieber, G.J. Siegel, T. Desmond, J. Lee-Hwa Liu, and S.A. Ernst \\ Laboratory of Neurochemistry, Department of Neurology (V.H., G.J.S., T.D.), and Department of Anatomy \\ and Cell Biology (J.L.-H.L., S.A.E.), University of Michigan Medical Center, Ann Arbor
}

A clone encoding mouse brain Na,K-ATPase $\alpha$-subunit was isolated from a mouse brain lambda gt11 cDNA library by using antisera to mouse and bovine brain $\alpha$-subunit. A comparison of the nucleotide sequence of this clone with published sequences of rat brain $\alpha$-subunit isoform clones showed it to be most similar to rat brain $\alpha 1$. An RNA antisense probe prepared from the cDNA insert of the mouse clone detected a single mRNA of approximately $4.5 \mathrm{~kb}$ in Northern blots of mouse brain and kidney RNAs. This probe hybridized only to an $\alpha 1$-cDNA insert from rat brain under high stringency conditions on Northern blots. The RNA antisense probe was used for in situ hybridization to sections of mouse kidney, cerebellum, and retina, and the cellular distribution of $\alpha$-subunit mRNA ( $\alpha$-mRNA) was compared with that of $\alpha$-subunit polypeptide ( $\alpha$-subunit) detected by immunofluorescence in similar sections. In kidney, $\alpha$-mRNA distribution closely paralleled that of the polypeptide with abundant expression in ascending thick limbs and cortical distal tubules and weaker labeling in cortical proximal tubules. The co-distribution of $\alpha$-mRNA and polypeptide in kidney where $\mathrm{Na}, \mathrm{K}-\mathrm{ATPase}$ localization is well established is consistent with the specificity of these probes. In the retina, prominent labeling with both probes was seen in photoreceptor inner segments, inner nuclear layer, and ganglion cell bodies. Plexiform layers and optic fibers expressed abundant $\alpha$-subunit but little mRNA. Light labeling for both was seen in the outer nuclear layer. In cerebellum, $\alpha$-mRNA and $\alpha$-subunit were associated with soma of granule cells, basket cells, and stellate cells. Glomeruli and basket terminals contained abundant $\alpha$-subunit but exhibited little reactivity with the riboprobe. In Purkinje cell bodies, in contrast, the antibody used to identify the cDNA clone did not resolve significant polypeptide in the somal plasmalemma despite abundant somal
mRNA expression. Comparison of distribution of the two probes in cerebellum and retina indicates that message accumulation is primarily in cell bodies, while $\alpha$-subunit epitopes may be co-expressed in cell bodies and/or transported to distant sites in cell-specific patterns.

Key words: sodium pump, in situ hybridization, immunocytochemistry

\section{INTRODUCTION}

$\mathrm{Na}, \mathrm{K}-\mathrm{ATP}$ ase is the membrane-bound enzyme that exchanges intracellular $\mathrm{Na}^{+}$for extracellular $\mathrm{K}^{+}$in animal cells (Skou, 1988). The resulting $\mathrm{Na}^{+}$and $\mathrm{K}^{+}$ gradients are critical for many general physiological processes, including regulation of cell volume and ion content. In addition, $\mathrm{Na}, \mathrm{K}$-ATPase activity is necessary for specialized functions unique to particular tissues, including maintenance of membrane electric potentials in excitable tissues and salt and water transport in osmoregulatory and exocrine epithelia. In accordance with its central role in such functions, high levels of the enzyme are present in tissues such as kidney and brain (Albers et al, 1989). Because of the different functions related to cation transport in these tissues and cell types, it is considered likely that there are cell-specific regulatory factors for this enzyme.

The enzyme consists of two polypeptide subunits, an $\alpha$-subunit of about $110 \mathrm{kDa}$ containing the catalytic site (Albers et al., 1989) and a $\beta$-subunit of about $40 \mathrm{kDa}$ whose function may be to stabilize and provide mem-

Received August 1, 1988; revised December 27, 1988; accepted December 28, 1988 .

Address reprint requests to Dr. V. Hieber, Department of Neurology, Rm. 1014 Neuroscience Lab Bldg., 1103 E. Huron St., University of Michigan, Ann Arbor, MI 48104-1687. 
brane insertion for the $\alpha$-subunit (Noguchi et al., 1987; Kawakami and Nagano, 1988). Two $\alpha$-subunit isoforms, $\alpha 1$ (previously termed $\alpha$, lower Mr) and $\alpha 2$ (previously termed $\alpha+$, higher Mr), with different electrophoretic mobility on sodium dodecyl sulfate polyacrylamide gel electrophoresis (SDS-PAGE), have been resolved in the brain and several other tissues of various animal species (Sweadner, 1979; Matsuda et al., 1984; Morohashi and Kawamura, 1984; Lytton et al., 1985; Siegel et al., 1986; Stahl, 1986; Charlemagne et al., 1987). ${ }^{1}$ Evidence from studies of genomic libraries suggest that four to five genes code for $\alpha$-subunit isoforms in man (Shull and Lingrel, 1987; Sverdlov et al., 1987). cDNAs for three separate $\alpha$-subunit isoforms, termed $\alpha 1, \alpha 2$, and $\alpha 3$, have been identified in rat brain (Shull et al., 1986; Herrera et al., 1987), and sequences coding for these isoforms have been mapped to three separate chromosomes in the mouse by using the rat isoform cDNAs as probes (Kent et al., 1987). Both $\alpha 2$ - and $\alpha 3$-cell-free translation products share common epitopes and comigrate at the same rate on SDS-PAGE (Schneider et al., 1988) so that the slower-moving band as seen by protein or immune staining (termed $\alpha+$ or $\alpha 2$ ) may be composed of both isoforms.

A number of reports have presented data concerning differential tissue expression of isoform-specific mRNAs by using blot hybridization methods (Emanuel et al., 1987; Herrera et al., 1987; Kent et al., 1987; Young and Lingrel, 1987; Schneider et al., 1988). Although important information concerning expression at the tissue or organ level is obtainable from such studies, differential expression of isoform-specific mRNA at cellular levels requires high-resolution in situ hybridization techniques. At present there is only a single report of in situ hybridization of $\alpha$-subunit isoform mRNA (Schneider et al., 1988). This survey examined expression of mRNAs of 18-day fetal rat tissues in whole body sagittal sections and also employed a probe for $\alpha 3$ mRNA to study regional expression in adult nervous system. $\alpha 3$-mRNA was localized in various portions of the forebrain and was largely restricted to the Purkinje cell layer in cerebellum (Schneider et al., 1988).

In order to study $\alpha$-subunit gene expression in the nervous system, we examined in parallel the cellular distribution of $\alpha$-subunit mRNA by high-resolution in situ hybridization and of $\alpha$-subunit polypeptide by immunocytochemistry. Mouse cerebellum and retina were selected as examples of well-defined CNS structures, and kidney was used to further verify probe specificity. We found proportionate colocalization of an $\alpha 1$-mRNA probe with $\alpha$ polypeptide immunoreactivity in perikarya

\footnotetext{
${ }^{1}$ The faster-moving band on electrophoresis is referred to as $\alpha 1$ and the
} slower-moving band as $\alpha 2$ (see also Schneider et al., 1988). of most cell types in cerebellum, retina, and kidney but not in neuronal extensions which were enriched in polypeptide. In Purkinje cells, however, abundant perikaryal mRNA was not accompanied by somal plasmalemma immunoreactivity, suggesting a different pattern of polypeptide expression or routing in these cells. A preliminary report of some of these data was published in abstract form (Hieber et al., 1988).

\section{MATERIALS AND METHODS \\ Materials}

Mice were purchased from Harlan Sprague Dawley, Inc. The mouse brain lambda gtl 1 library was from Clontech. Rat $\alpha$-subunit isoform clones were generous gifts from Robert Levenson (Yale University, New Haven, CT) and Jerry Lingrel (University of Cincinnati College of Medicine, Cincinnati, OH). pGEM vectors and in vitro transcription kits were from Promega Biotec. Restriction enzymes and other enzymes used for subcloning and sequencing were from Bethesda Research Laboratories (BRL) or Boehringer Mannheim. Radioisotopes were purchased from Amersham. Prestained protein standards for electrophoresis were obtained from BRL and Sigma while SDS (catalogue \#L-5750) was obtained from Sigma. Immunochemicals were obtained from ICN Biomedicals, Inc.

\section{Preparation of Na,K-ATPase and Antisera Against $\alpha$-Subunit}

Mouse brain. The antimouse brain $\alpha$-subunit antiserum (27C) was prepared and characterized as previously described (Siegel et al., 1984, 1986; Ernst et al., 1986).

Bovine brain. Sucrose-gradient fractions enriched in $\mathrm{Na}, \mathrm{K}$-ATPase were prepared from bovine brain and $\alpha$-subunits were resolved on slab gels $(160 \times 140 \times 1.5$ $\mathrm{mm}$ ) of $6 \%$ polyacrylamide as described (Siegel et al., 1986). For preparation of $\alpha$-subunits for inoculation, $20 \%$ sucrose-gradient enzyme (Siegel et al,, 1984, 1986), $3 \mathrm{mg}$ protein, was applied to the whole slab for electrophoresis. Horizontal strips of gel containing combined $\alpha 1$ and $\alpha 2$ were sliced out of the unfixed, frozen gel and the polypeptides were electroeluted with an ISCO Electrophoretic Sample Concentrator model 1750. Rabbit polyclonal antibody (31B) was generated by methods described previously (Siegel et al., 1984) and specificity was established on immunoblots and by immunocytochemistry (see Results). SDS-PAGE (Laemmli, 1970), electroblotting (Towbin et al., 1979), and immunostaining procedures were performed as described (Siegel et al., 1986).

\section{Isolation and Characterization of cDNA Clones}

A mouse brain lambda gt 11 expression library was plated with bacterial strain Y1090 at approximately 
5,000 plaque-forming units per $100 \mathrm{~mm}$ plate. The library was grown and the plaques screened with polyclonal antisera against mouse brain and bovine brain $\alpha$ subunit according to the procedure of Young and Davis (1985).

Antisera were used for library screening at a 1:500 dilution. The bovine $\alpha$-subunit antiserum was used for initial screening of the library because it was available in a larger quantity. Clones reactive with the bovine antisera were plaque-purified and tested with the mouse $\alpha$ subunit antiserum, which was available in only a limited amount. Those reacting with both antisera, and therefore more likely to represent $\alpha$-subunit clones, were used for further studies. Bacteriophage DNA was isolated from plate lysates (Maniatis et al., 1982), and cDNA inserts from the bacteriophage DNA were subcloned into M13 vectors mp18 and mp19. The inserts were isolated from the intracellular bacteriophage RF for probe synthesis and restriction enzyme analysis. The single-stranded extracellular bacteriophage was used for sequencing.

\section{DNA Sequence Analysis}

DNA sequence analysis was performed by the dideoxynucleotide chain-termination method of Sanger et al. (1977). Subclones of each cDNA insert in opposite orientation in the sequencing vectors were sequenced from the ends toward the center of the insert. Average lengths of 200-300 nucleotides were obtained. Each region was sequenced at least twice to confirm sequences. Sequences were combined and analyzed, translated, and compared with available ATPase sequences by using the Protein Identification Resource (Biomedical Research Foundation, Georgetown University Medical Center) (George et al., 1986).

\section{Probe Synthesis}

Several types of probes were prepared and used in these studies. Initially cDNA inserts isolated from mp18 and mp 19 vectors were nick-translated (Weinstock et al., 1978) in the presence of ${ }^{32} \mathrm{P}$-dCTP for Southern blot studies. For Northern blot and in situ hybridization studies, a cDNA insert of $483 \mathrm{bp}$, corresponding to the middle of the coding region for the rat $\alpha 1$-isoform, was inserted into the pGEM4 vector. RNA probes were prepared by transcription from the linearized vector in the presence of labeled nucleotide by using either T7 or SP6 polymerase to produce the sense or antisense transcripts as described previously (Bevilacqua et al., 1988); ${ }^{32} \mathrm{P}$-labeled transcripts were prepared by polymerization in the presence of ${ }^{32} \mathrm{P}$-UTP- and ${ }^{35} \mathrm{~S}$-labeled transcripts by polymerization in the presence of ${ }^{35} \mathrm{~S}$-thio-labeled nucleoside triphosphates.

\section{Northern and Southern Blot Analysis}

Total cellular RNA was isolated from brain and kidney of 3-week-old DBA mice by the method of Strohman et al. (1977). Total RNA was separated on $1 \%$ agarose gels containing $2.2 \mathrm{M}$ formaldehyde according to the procedure of Lehrach et al. (1977). The RNA was transferred to GeneScreen membranes (New England Nuclear). Hybridization to labeled probes was carried out at $65^{\circ} \mathrm{C}$ with prehybridization, hybridization, and subsequent washing of filters as described previously (Bevilacqua et al., 1988).

Restriction fragments from rat $\alpha$-isoform cDNAs were separated on $1 \%$ agarose gels in Tris-acetate-EDTA buffer (Maniatis et al., 1982) and subsequently transferred to GeneScreen membranes (New England $\mathrm{Nu}$ clear). Hybridization to labeled probes was carried out at $42^{\circ} \mathrm{C}$ in $50 \%$ formamide (Meinkoth and Wahl, 1984) for 18-24 hr. Low-stringency washing was done in $2 \times$ SSC- $0.1 \%$ SDS for $10 \mathrm{~min}$ at room temperature, in $1 \times$ SSC $-0.1 \%$ SDS for $10 \mathrm{~min}$ at $50^{\circ} \mathrm{C}$, and finally in $0.5 \times$ SSC- $0.1 \%$ SDS for $1 \mathrm{hr}$ at $50^{\circ} \mathrm{C}$. High-stringency washes were subsequently carried out in $0.1 \times$ SSC-0.1\% SDS for $1 \mathrm{hr}$ at $65^{\circ} \mathrm{C}$. Hybridization was detected by autoradiography by using Kodak XAR-5 x-ray film.

\section{Tissue Preparation}

Mice (CBA strain) were anesthetized by intraperitoneal injection with sodium pentobarbital and perfused via the left ventricle for approximately $1 \mathrm{~min}$ with phosphate-buffered saline (PBS) and then with approximately $20 \mathrm{ml}$ of $2-4 \%$ paraformaldehyde in $0.1 \mathrm{M}$ phosphate buffer ( $\mathrm{pH} 7.4$ ) over a 5 min period. Kidney, retina, and cerebellum were removed, cut into small tissue blocks, and postfixed in the same fixative for $2 \mathrm{hr}$. Fixed tissues were rinsed in buffer and then infiltrated with $20 \%$ sucrose in phosphate buffer and frozen in a mixture of acetone, hexane, and dry ice. Sections $(10 \mu \mathrm{m})$ were cut in a cryostat and mounted on slides coated with either gelatin or poly-L-lysine.

\section{In Situ Hybridization}

The procedures employed for in situ hybridization followed those described by Watson et al. (1987). Briefly, cryostat sections of formaldehyde-fixed tissues were deproteinated with proteinase $\mathrm{K}(1 \mu \mathrm{g}$ protein-

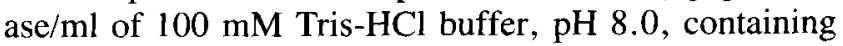
$50 \mathrm{mM}$ EDTA) for $30 \mathrm{~min}$ at $37^{\circ} \mathrm{C}$ and rinsed with distilled water. Sections were then incubated for $1 \mathrm{~min}$ in $0.1 \mathrm{M}$ triethanolamine- $\mathrm{HCl}(\mathrm{pH} 8.0)$ and for $10 \mathrm{~min}$ at room temperature in $0.1 \mathrm{M}$ triethanolamine- $\mathrm{HCl}(\mathrm{pH}$ 8.0) diluted with acetic anhydride (final concentration $0.25 \%, \mathrm{vol} / \mathrm{vol}$ ) to reduce electrostatic binding of probes. After washing for $5 \mathrm{~min}$ in $2 \times \mathrm{SSC}$, sections 
were dehydrated through increasing concentrations of ethanol and air-dried. Sections were covered with an aliquot of hybridization buffer (final concentrations of $75 \%$ formamide, $10 \%$ dextran sulfate, $3 \times \mathrm{SSC}, 50 \mathrm{mM}$ sodium phosphate buffer $\mathrm{pH} 7.4,1 \times$ Denhardt's solution, $0.1 \mathrm{mg} / \mathrm{ml}$ yeast tRNA, and $0.1 \mathrm{mg} / \mathrm{ml}$ sonicated, denatured salmon sperm DNA) containing approximately $1 \times 10^{6} \mathrm{cpm}$ of the radioactive probe and sealed with coverslips. Dithiothreitol $(10 \mathrm{mM})$ was added for ${ }^{35} \mathrm{~S}$-labeled probes. Sections were hybridized for $21 \mathrm{hr}$ at $50^{\circ} \mathrm{C}$. Coverslips were then removed, and the sections were washed in $2 \times \mathrm{SSC}$ for $5 \mathrm{~min}$ at room temperature. Sections were then incubated for $30 \mathrm{~min}$ at $37^{\circ} \mathrm{C}$ with RNase A, $200 \mu \mathrm{g} / \mathrm{ml}$, in $0.5 \mathrm{M} \mathrm{NaCl}$ and $10 \mathrm{mM}$ Tris$\mathrm{HCl}$ buffer $(\mathrm{pH} 8.0)$. The sections were further washed in $2 \times \mathrm{SSC}$ for $10 \mathrm{~min}$, in $1 \times \mathrm{SSC}$ for $10 \mathrm{~min}$, in 0.5 $\times \mathrm{SSC}$ for $60 \mathrm{~min}$ at $50^{\circ} \mathrm{C}$, and finally in $0.5 \times \mathrm{SSC}$ for $10 \mathrm{~min}$ at room temperature.

\section{Autoradiography}

For rapid detection of hybridization with 32P-labeled probes, slides were air-dried and exposed in a cassette to Kodak XAR-5 x-ray film for 24-48 hr. Highresolution autoradiograms with ${ }^{35} \mathrm{~S}$-labeled probes were produced by dipping dried sections in Kodak NTB-2 emulsion (diluted 1:1 with distilled water), exposing the sections at $4^{\circ} \mathrm{C}$ until the desired grain density was obtained (3-6 days), and then developing the emulsion with D-19 developer. Sections were analyzed and photographed with darkfield, differential interference contrast (DIC), and phase-contrast optics.

\section{Immunofluorescence Studies}

Cryostat sections were exposed to $1 \%$ normal goat serum in phosphate-buffered saline (NGS/PBS) followed by incubation with bovine $\alpha$-subunit antiserum 31B for 1 $\mathrm{hr}$ at room temperature and $12 \mathrm{hr}$ at $4^{\circ} \mathrm{C}$ in a moist chamber. Serial dilutions of primary antibody with NGS/ PBS were used to establish the optimal dilution for each antibody. Sections were rinsed with NGS/PBS and then exposed for $1 \mathrm{hr}$ at room temperature to FITC-conjugated goat antirabbit IgG diluted 1:50 with NGS/PBS. Sections were washed with PBS, coverslipped with a mixture of $90 \%$ glycerol, $10 \%$ PBS, and $0.1 \%$ p-phenylenediamine, and examined and photographed with a Leitz fluorescence microscope.

\section{RESULTS}

\section{Characterization of Bovine Brain $\alpha$-Subunit Antiserum}

Specificity of antiserum to bovine brain $\alpha$-subunit (31B) was tested on immunoblots of mouse and bovine brain whole homogenates and fractions. Bands identified as $\alpha 1$ - and $\alpha 2$-isoforms were specifically stained in mouse and bovine brain whole homogenates (Fig. 1A, lanes 3,4 ) and in the enriched sucrose gradient fractions (Fig. 1B, lanes 3,4). None of the other proteins in the whole homogenates or fractions was significantly stained by the antiserum (compare to Coomassie blue stain for protein in Fig. 1, lanes 1,2).

\section{Isolation and Analysis of Mouse Brain $\alpha$-Subunit cDNA}

Approximately 50,000 plaques from a lambda gt 11 cDNA expression library constructed from brain mRNA of adult Swiss-Webster mice were screened, and eight clones were isolated and purified after being shown to react with antiserum 31B to bovine $\alpha$-subunit. All clones reacting positively with $31 \mathrm{~B}$ also reacted with antiserum to mouse brain (27C) $\alpha$-subunit. The clones contained inserts of $100-650 \mathrm{bp}$ in length. These inserts were subcloned directly into M13 sequencing vectors mp18 and mp19 and sequenced.

Because of the previously shown homology between $\alpha$-isoforms of different species (Shull et al., 1985, 1986; Kawakami et al., 1986; Ovchinnikov et al., 1986; Herrera et al., 1987), the mouse brain cDNA sequences obtained in this study were compared with those published for rat brain $\alpha$-isoforms (Shull et al., 1986; Herrera et al., 1987). Seven of the isolated clones showed similarity to rat brain $\alpha$-isoforms. A clone of $483 \mathrm{bp}$ (designated mb4a) showing sequence similarity to rat brain $\alpha 1$ was used to develop a probe for in situ hybridization studies. This clone was chosen for such use because of its length, being larger than all but one of the other positively reacting clones, and its similarity to rat $\alpha 1$, suggesting a mouse $\alpha$-isoform which should be present in all tissues examined. By comparison with rat brain $\alpha 1$, mb4a extends from the middle of the $\mathrm{H} 4$ hydrophobic region through the phosphorylation site and ends 45 bp upstream from the FITC binding site. An alignment of a portion of the nucleotide sequence of mb4a extending from the 5 ' end of the cDNA through the phosphorylation site with that of the rat brain $\alpha 1$ sequence for this region is shown in Figure 2. This region was sequenced numerous times to resolve all ambiguities. A comparison of the total sequence of mb4A to published rat brain $\alpha$-isoform sequences taking all ambiguities into account revealed $>80 \%$ identity at the nucleotide level and $90 \%$ similarity at the amino acid level to rat brain $\alpha 1,>78 \%$ identity at the nucleotide level and $88 \%$ similarity at the amino acid level to rat brain $\alpha 2$, and $>75 \%$ identity at the nucleotide level and $85 \%$ similarity at the amino acid level to rat brain $\alpha 3$. The percent identity between the nucleotide sequences for the coding regions of the rat $\alpha$ isoforms themselves ranged from $76 \%$ to $79 \%$ (Shull et al., 1986). A comparison of the 

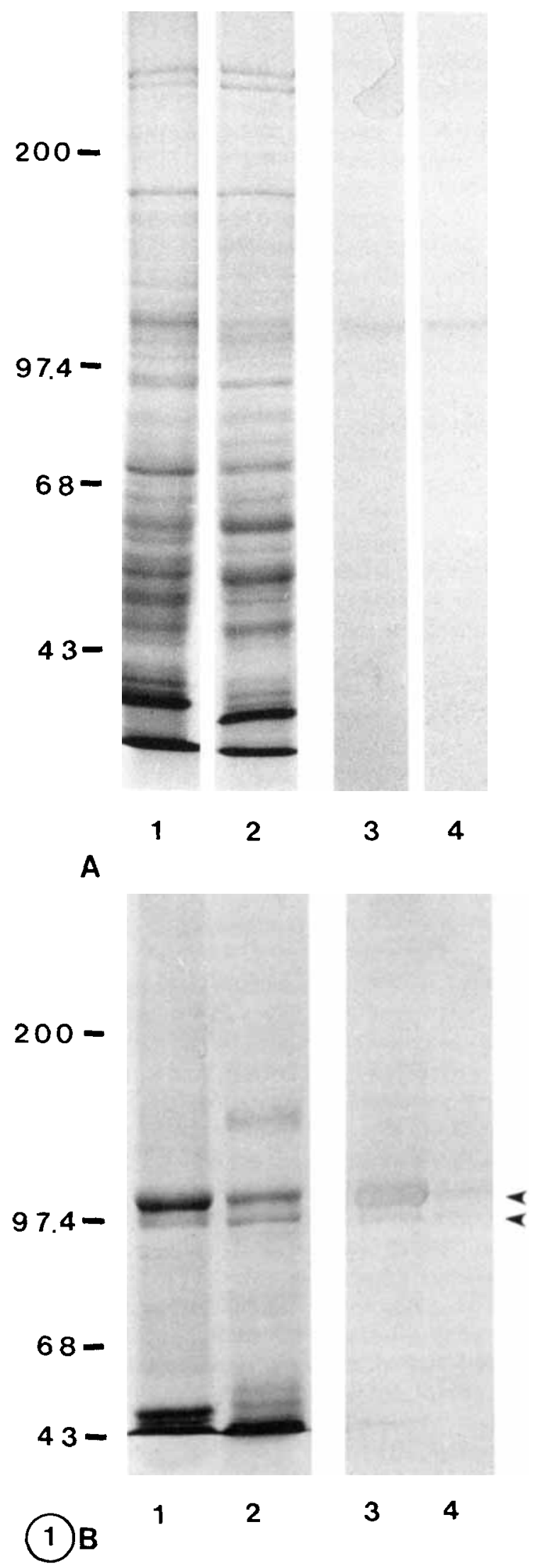

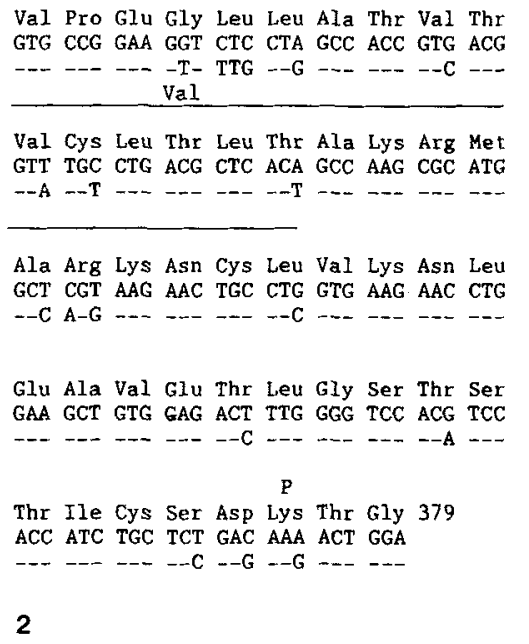

Fig. 2. Nucleotide sequence analysis of mb4a cDNA. The nucleotide and deduced amino acid sequence of a portion of the clone are compared with those of the corresponding region of rat brain $\alpha 1$ subunit. Differences from the rat nucleotide and amino acid sequences are indicated below the sequences for the mouse clone. The amino acid sequence starts with amino acid 332 in the middle of $\mathrm{H} 4$ hydrophobic region of the rat sequence and extends past the phosphorylation site to amino acid 379 . The $\mathrm{H} 4$ hydrophobic region is underlined and the phosphory lation site is indicated by the letter $P$.

mb4a sequence to that of rat stomach H,K-ATPase (Shull and Lingrel, 1986) indicated much less homology, with $65 \%$ identity at the nucleotide level and $75 \%$ at the amino acid level.

\section{Comparison of Mouse With Rat $\alpha$-Isoform cDNAs}

The similarity of the mouse clone to the rat $\alpha 1$ isoform of $\mathrm{Na}, \mathrm{K}$-ATPase was also tested by hybridization of the mouse cDNA probe under stringent conditions to cDNA inserts coding for the three rat brain $\alpha$-isoforms (Fig. 3A). Under these conditions, the probe hybridized to the rat $\alpha 1$-isoform only. Under the lower-stringency post-hybridization washing conditions (Fig. 3B), reaction with $\alpha 2$ - and $\alpha 3$-cDNA inserts was also seen but was much less intense than with $\alpha 1$. This probe hybridized strongly with restriction fragments from the middle

Fig. 1. Immunoblots with antibovine brain $\mathrm{Na}, \mathrm{K}$-ATPase catalytic $(\alpha 1+\alpha 2)$ subunit. A: Whole brain homogenates. B: $20 \%$ sucrose gradient brain fractions enriched in $\mathrm{Na}, \mathrm{K}$ ATPase. Lanes 1 and 2: Coomassie blue stain. Lanes 3 and 4: Immunoblot with 31B antiserum, 1:500 dilution. Mouse brain, lanes 1 and 3 ; bovine brain, lanes 2 and 4 . Arrowheads indicate $\alpha 2$ (higher Mr) and $\alpha 1$ (lower Mr). Little or no $\alpha 1$ is seen in the whole homogenates (A) because of its relatively low concentration, but substantial amounts of $\alpha 1$ together with $\alpha 2$ are seen in the enriched fractions, and the ratio of $\alpha 2: \alpha 1$ is higher in mouse than in bovine brain (B). 


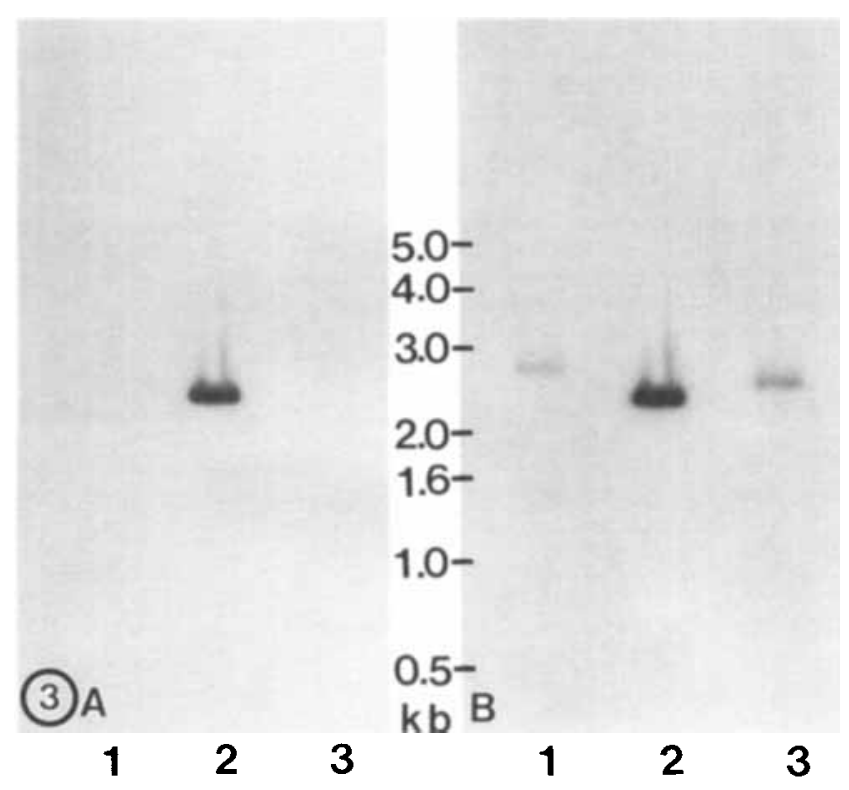

Fig. 3. Hybridization of mouse cDNA probe to restriction fragments of rat $\alpha$-isoform clones. A: Stringent conditions. B: Nonstringent conditions. Lane 1: Rat $\alpha 3$. Lane 2: Rat $\alpha 1$. Lane 3: Rat $\alpha 2$. Molecular weight standards in $\mathrm{kb}$ are indicated in the middle.

of the coding region of the rat $\alpha 1$-cDNA containing the $\mathrm{H} 4$ hydrophobic region and phosphorylation site and weakly with restriction fragments from rat $\alpha 2$ - and $\alpha 3-$ cDNAs containing these regions. No reaction was found with other restriction fragments outside this region (data not shown).

\section{Northern Blot and In Situ Hybridization Studies With ${ }^{32}$ P-Riboprobes}

The cDNA insert from clone mb4a was transferred to the vector pGEM 4 and ${ }^{32} \mathrm{P}$-labeled sense and antisense RNA transcripts were prepared. Hybridization of the RNA probes to Northern blots revealed a single band of approximately $4.5 \mathrm{~kb}$ in brain and kidney RNAs with the antisense probe and no hybridizing bands with the sense probe (Fig. 4). Bands of identical size were detected on a similar Northern blot by using rat $\alpha 1$-cDNA as a probe (data not shown). The same ${ }^{32} \mathrm{P}-$ labeled probe was used for in situ hybridization with sections of mouse kidney and retina. A strong hybridization signal was resolved in both tissues with the antisense probe (Fig. 5A). Resolution in kidney was sufficient to indicate a regional distribution of probe similar to that seen previously for catalytic subunit by cytochemistry (Ernst and Schreiber, 1981) and immunocytochemistry (Siegel et al., 1984; Kashgarian et al., 1985)-namely, intense labeling of outer medulla, moderate reactivity of cortex, and undetectable labeling of inner medulla. No hybridization was observed in sections exposed to the sense probe (Fig. 5B).

\section{In Situ Localizations With ${ }^{35}$ S-Riboprobe and $\alpha$-Subunit Antiserum}

A ${ }^{35}$ S-labeled antisense probe was prepared for in situ hybridization to sections of mouse kidney, cerebellum, and retina to permit detection of regions of hybridization with greater resolution. Probe distribution in autoradiograms of the tissues was viewed with darkfield, DIC, and phase optics and was compared to the distribution of $\alpha$-subunit as revealed by immunofluorescent staining with $31 \mathrm{~B}$. There was no specific immunofluorescence staining with preimmune serum controls (data not shown).

Kidney. In kidney, both the mRNA (Fig. 6A) and the polypeptide (Fig. $6 \mathrm{~B}$ ) probes strongly labeled tubules in the outer medulla, whereas tubules in the inner medulla were not labeled above background levels. With DIC optics, the regional distribution of riboprobe was resolved as intense labeling of ascending thick limbs in outer medulla (not shown) and their extensions as distal tubular segments in the cortex (Fig. 6C). In contrast, proximal tubules in the cortex were moderately labeled and collecting tubules were lightly labeled. At the cellular level, $\alpha$-subunit mRNA appeared uniformly distributed in the cytoplasm. The tubule-specific pattern and intensity of mRNA distribution paralleled that of the $\alpha$ subunit as revealed by immunofluorescence (Fig. 6B).

Retina. Distribution of $\alpha$-mRNA and $\alpha$-subunit among the various retinal layers is compared in the darkfield and fluorescence images shown in Figure 7A and 7B. More detailed resolution of probe distribution is seen in Figure 7C. Prominent labeling of mRNA with the antisense probe was detected in inner segments of the photoreceptor layer, in cell bodies of the inner nuclear layer, and in ganglion cell bodies of the ganglion cell/ optic fiber layer (Fig. 7A,C). In these layers, distribution of mRNA was paralleled by intense $\alpha$-subunit immunofluorescence (Fig. 7B). The outer nuclear layer of the photoreceptor cells showed scattered foci of mRNA label (Fig. 7A,C) and a reticular pattern of weak to moderate immunofluorescence which is probably associated with Müller cells (McGrail and Sweadner, 1986) and possibly with photoreceptor plasma membrane (Fig. 7B). The regions with high concentrations of cell processes and synapses composing the inner and outer plexiform layers were relatively free of $\alpha$-subunit message (Fig. 7A,C). In marked contrast, the $\alpha$-polypeptide was intensely expressed in both of the plexiform layers and in the optic nerve fibers (Fig. 7B).

Cerebellum. In cerebellar cortex, pronounced expression of $\alpha$-subunit mRNA was visualized as focal accumulations of autoradiographic grains in molecular, 
Purkinje cell, and granular layers, whereas white matter was unlabeled (Fig. 8A). As shown in phase contrast (Fig. 8B), Purkinje cell bodies were heavily labeled, as were basket cell and outer stellate cell bodies in the overlying molecular layer. There were areas of less intense labeling throughout the neuropil of the molecular layer, but resolution was not sufficient to discriminate between neuronal extensions and glial components. In the granular layer, autoradiographic grains were associated with granule cell perikarya, whereas glomeruli, which consist of multiple granule cell dendrites, a mossy fiber terminal, a Golgi cell axon, and astrocytic processes, were poorly labeled (Fig. 8B). Immunofluorescence localization of $\alpha$-subunit polypeptide in mouse cerebellum with 31B (Fig. 8C) showed intense immunostaining of basket cell terminal regions associated with Purkinje cells. In contrast, immunofluorescence localization with $31 \mathrm{~B}$ revealed little if any reactivity in Purkinje cell perikarya, despite the presence of abundant message (compare to Fig. $8 \mathrm{~A}$ and $8 \mathrm{~B}$ ), or in proximal dendritic plasmalemma. In the granular layer, glomeruli and borders of granule cell perikarya were strongly immunoreactive for $\alpha$-subunit polypeptide (Fig. 8C). Cell bodies in the molecular layer were also outlined by immunofluorescence and the surrounding neuropil was diffusely stained.

\section{DISCUSSION}

We have isolated a cDNA clone corresponding to a portion of mouse brain Na,K-ATPase $\alpha$-subunit mRNA and have demonstrated its use for in situ studies of sodium pump expression at the transcriptional level in mouse brain, kidney, and retina. An antibody probe to the $\alpha$-subunit was used in parallel studies to determine the distribution of the translated polypeptide.

\section{Characterization of Probe}

A Na,K-ATPase $\alpha 1$-subunit probe was chosen for these initial studies because of its widespread occurrence in animal tissues (Herrera et al., 1987; Kent et al., 1987; Young and Lingrel, 1987). This cDNA was selected from a lamda gt 11 expression library because the fusion protein expressed by phage clones containing the cDNA reacted with polyclonal antisera to both bovine and mouse brain $\alpha$-subunit. We conclude that the cDNA we have isolated corresponds to the $\alpha 1$-isoform based on the following lines of evidence: 1) sequence identity was greatest to rat $\alpha 1$-isoform in comparison to $\alpha 2$ and $\alpha 3$ (Shull et al., 1986; Herrera et al., 1987); 2) hybridization was strongest to restriction fragments from a rat $\alpha 1$ isoform clone as compared to similar fragments from $\alpha 2$ and $\alpha 3$ isoform clones (Fig. 3);3) the cDNA clone hybridized to an abundant mRNA of approximately $4.5 \mathrm{~kb}$ in both mouse brain and kidney (Fig. 4). Rat $\alpha 1$-cDNA

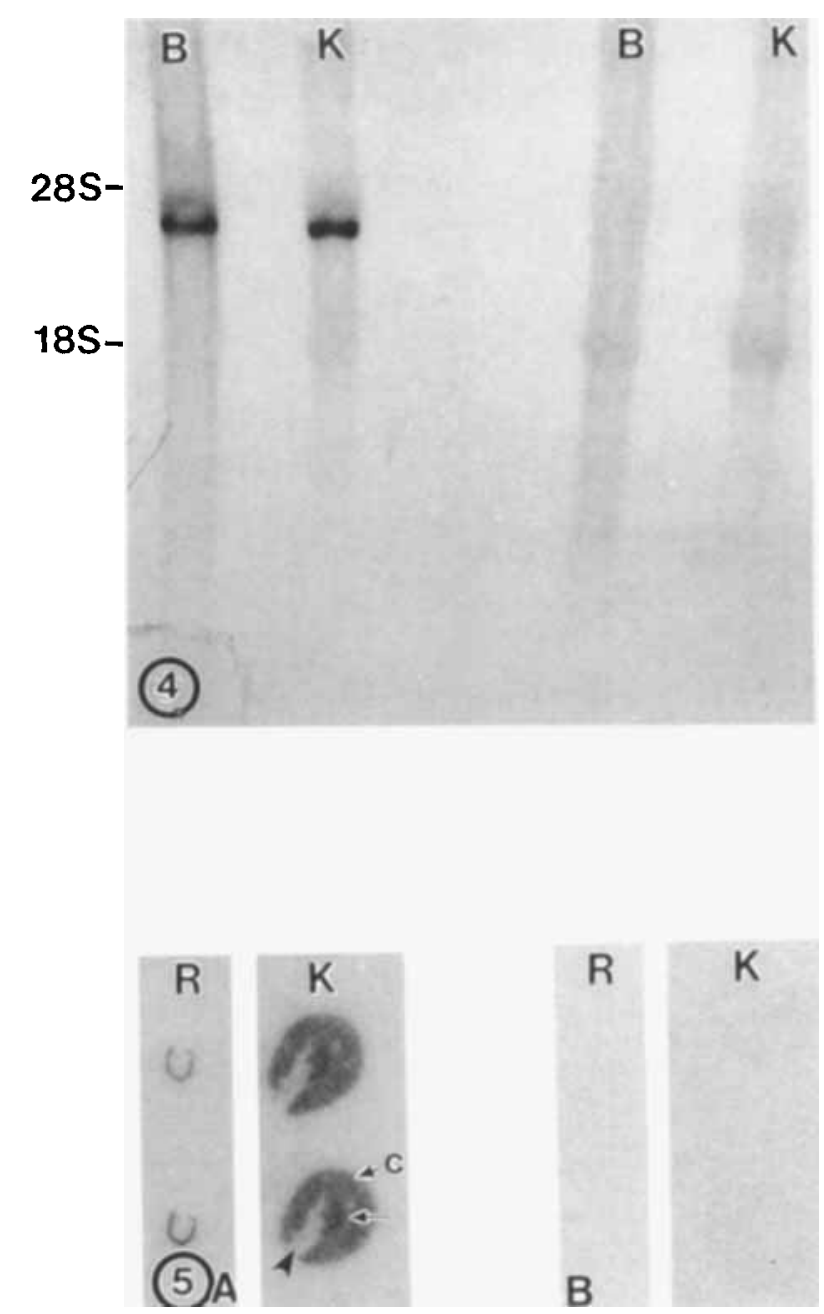

Fig. 4. Northern blot analysis of mouse brain and kidney RNA with mouse $\alpha$-subunit antisense and sense RNA probes. Total cellular RNA $(20 \mu \mathrm{g})$ from mouse brain (B) and kidney (K) was electrophoresed in a $1 \%$ agarose/2.2M formaldehyde gel and transferred to GeneScreen. RNA homologous to the $\alpha$-subunit was located by hybridization of RNA on the membrane to ${ }^{32} \mathrm{P}$-labeled antisense (pair of lanes on left) and sense (pair of lanes on right) RNA probes $\left(1 \times 10^{8} \mathrm{cpm} / \mu \mathrm{g}\right)$ followed by autoradiography. Positions of $28 \mathrm{~S}$ and $18 \mathrm{~S}$ ribosomal RNA markers are as indicated.

Fig. 5. In situ hybridization of ${ }^{32} \mathrm{P}$-labeled mouse $\alpha$-subunit RNA probes to mouse retina and kidney sections. Cryostat sections of mouse retina and kidney were prepared and hybridized to the antisense (A) and sense (B) RNA probes described in the legend to Figure 4. Sections were exposed directly to $\mathrm{x}$-ray film for detection of hybridization. C, cortex; arrow, outer medulla; arrowhead, inner medulla.

has also been reported to hybridize to mRNA of this size in rat brain and kidney (Herrera et al., 1987; Kent et al., 1987). Since levels of mRNA for $\alpha 2$ and $\alpha 3$ are very low 

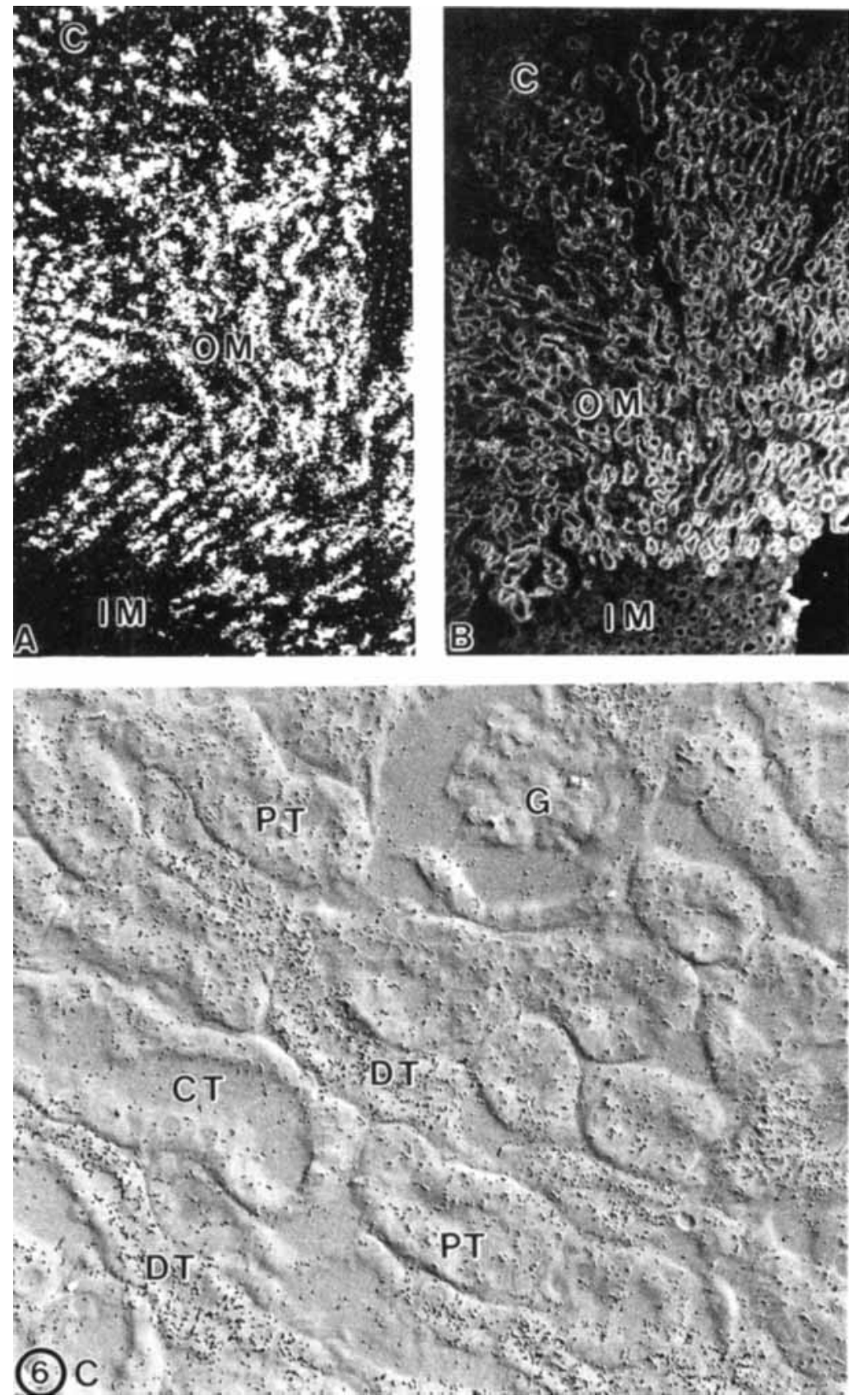

Fig. 6. Localization of $\alpha$-subunit mRNA and polypeptide in mouse kidney. A: ${ }^{35} \mathrm{~S}$-labeled $\mathrm{mRNA}$ probe hybridized strongly with tubules in outer medulla (OM), identified histologically as thick ascending limbs, and scattered tubules in cortex (C). Tubules in the inner medulla (IM) were unlabeled. B: The distribution of immunostaining with $31 \mathrm{~B}$ antiserum to the $\alpha$ -

or nonexistent in adult rat kidney (Herrera et al., 1987; Kent et al., 1987), it is evident that the abundant target recognized by the probe in kidney is $\alpha 1-\mathrm{mRNA}$.

Light reactivity of the mouse cDNA clone to rat $\alpha 2$ and $\alpha 3$ was seen only with low-stringency washing con- subunit paralleled that seen with the riboprobe. C: In thecortex, distal tubules (DT) expressed abundant $\alpha$-mRNA, whereas proximal tubules (PT) and collecting tubules (CT) expressed moderate and low hybridization signals, respectively. G, glomerulus. A: autoradiogram, darkfield optics. $\times 70$. B: epifluorescence. $\times 65$. C: autoradiogram, DIC optics. $\times 345$.

ditions following blot hybridization (Fig. 3B). This is to be expected since there is some sequence similarity to the rat $\alpha 2$ - and $\alpha 3$-isoforms. Therefore, under the conditions of in situ hybridization using the mouse cRNA probe in this study (i.e., moderate stringency), some small 

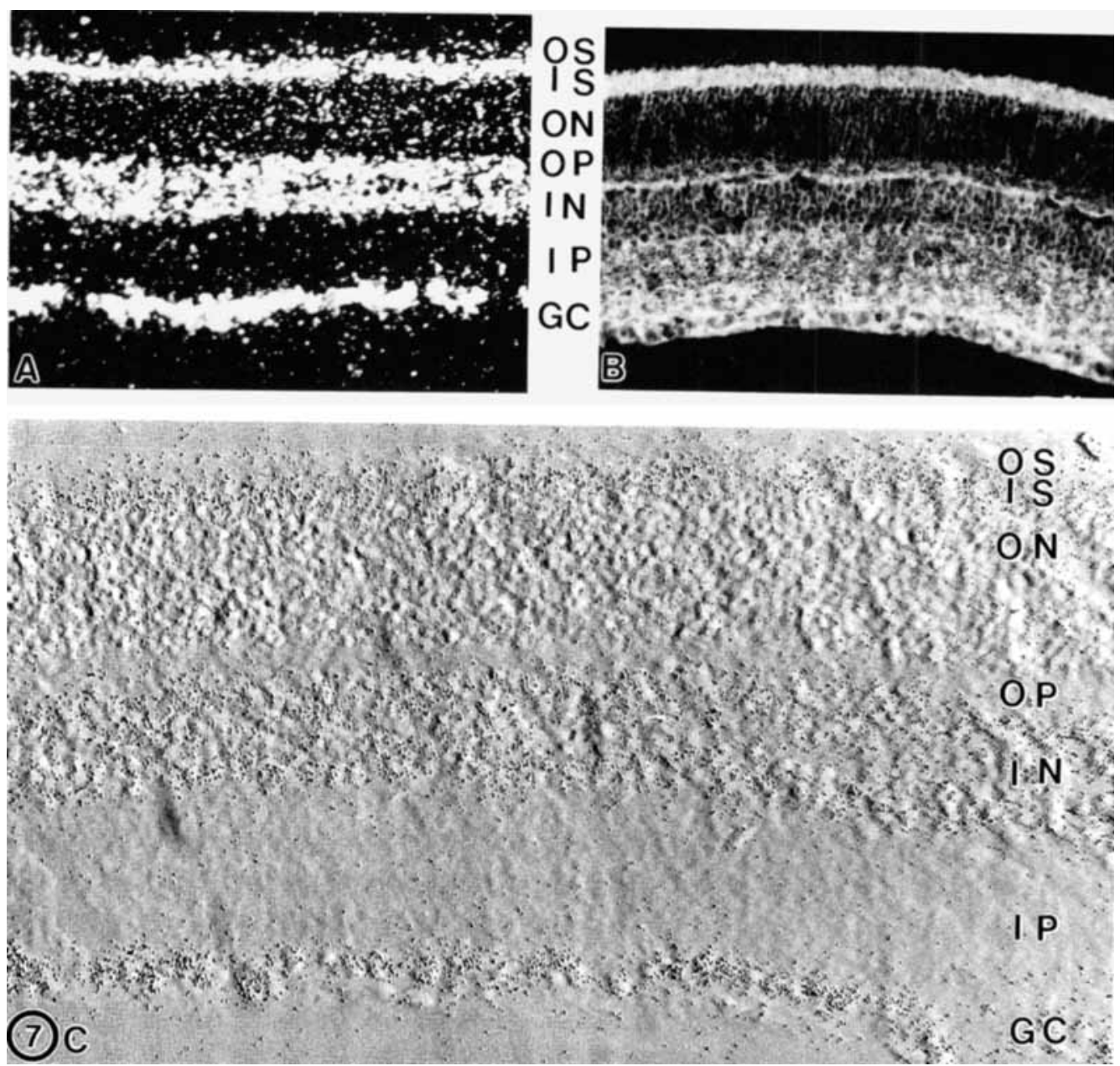

Fig. 7. Localization of $\alpha$-subunit mRNA and polypeptide in mouse retina. In situ hybridization of ${ }^{35} S$-labeled $\alpha$-subunit mRNA probe as revealed by darkfield (A) and DIC (C) optics is compared to immunofluorescence staining with $31 \mathrm{~B}$ antiserum to $\alpha$-subunit polypeptide (B). See text for description. OS,

amount of detection of $\alpha 2$ - and $\alpha 3-$ mRNAs in addition to $\alpha 1$ cannot be excluded.

\section{Localization in Kidney}

The pattern of riboprobe distribution in kidney (Figs. 5, 6A,C) paralleled immunofluorescence localization with $31 \mathrm{~B}$ (Fig. 6B) and previously reported immunoperoxidase staining with antiserum to mouse brain $\alpha$ subunit (Siegel et al., 1984). The tubule-specific pattern and intensity of reactivity with both probes correspond to the distribution of $\mathrm{Na}, \mathrm{K}$-ATPase protein as seen by immunoelectron microscopy (Kashgarian et al., 1985) and enzymatic activity as revealed by histochemical methods (Ernst, 1975; Ernst and Schreiber, 1981). Taken together, the data strongly support the specificity of antiserum 31B and the riboprobe for sequences of the $\alpha$-subunit protein outer segments; IS, inner segments; ON, outer nuclear layer; $\mathrm{OP}$, outer plexiform layer; IN, inner nuclear layer; IP, inner plexiform layer; GC, ganglion cell layer. A, $\times 165 . \mathrm{B}, \times 150$. C, $\times 330$.

and message. It is presumed that all the mRNA label and immunoreactivity shown in the kidney is $\alpha 1$-isoformspecific, since all other known Na,K-ATPase mRNAs have been shown by blot hybridization to be absent or in very low quantity relative to $\alpha 1$ in adult rat kidney (Herrera et al., 1987; Young and Lingrel, 1987; Emanuel et al., 1987; Schneider et al., 1988). The relative abundance of mRNA was proportionate to that of polypeptide in each region of kidney. This suggests a coordination or linkage between mRNA synthesis and translation in this tissue. Within the various tubular cells, mRNA appeared uniformly distributed throughout the cytoplasm. The polarized distribution of protein to the basolateral membrane (Ernst, 1975; Ernst and Schreiber, 1981; Siegel et al., 1984; Kashgarian et al., 1985) was not reflected by a similar asymmetrical compartmentation of mRNA. Thus, 


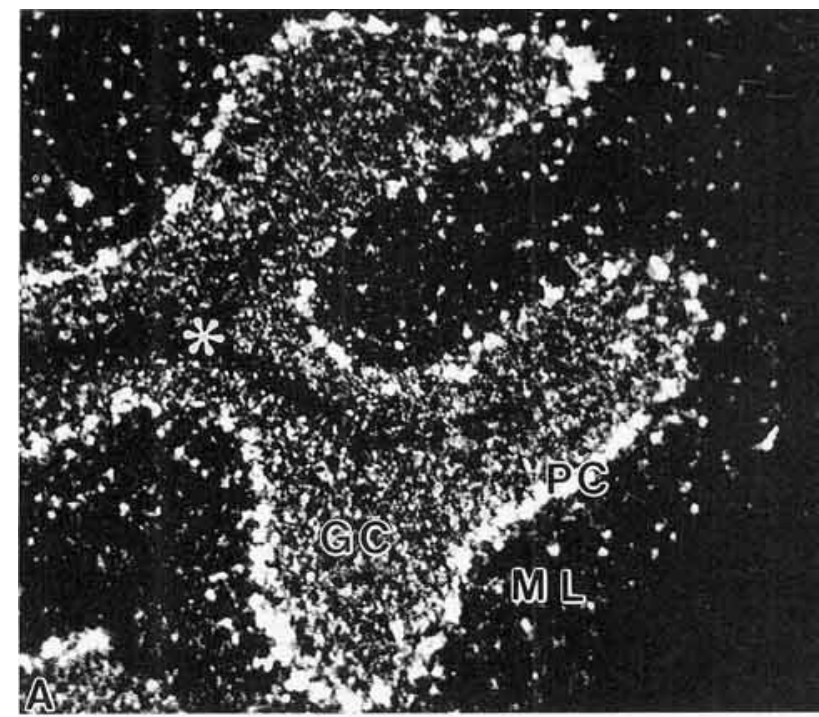

the routing mechanism for polarization of the membranebound enzyme begins with or after polypeptide synthesis.

\section{Localization in Retina}

In retina, $\alpha$-mRNA and $\alpha$-polypeptide are strongly expressed in the inner segments of photoreceptor cells (Fig. 7), which is the site responsible for the bulk of protein synthesis, and for Na,K-ATPase-dependent maintenance of the dark current (Barnstable, 1987). The inner nuclear layer and ganglion cells in the optic fiber layer also expressed abundant message (Fig. 7A,C) and, in agreement with the results of McGrail and Sweadner (1986), cell bodies and processes in these layers were strongly immunoreactive for the $\alpha$-subunit (Fig. 7B). In addition, in studies of dissociated retinal cells with the antiserum used in this study, abundant $\alpha$-subunit was resolved in ganglion cell and bipolar cell dendritic processes as well as in soma and axonal processes (unpublished data; see also McGrail and Sweadner, 1986). The virtual absence of resolvable $\alpha$-mRNA in both plexiform layers (Fig. 7A,C) despite their abundant expression of $\alpha$-subunit (Fig. 7B) is consistent with transport of $\mathrm{Na}, \mathrm{K}$ ATPase from sites of synthesis in neuronal cell bodies to destinations in cell processes and synapses (see Specht and Sweadner, 1984). It cannot be ruled out, however, that the amount of dendritic $\alpha$-mRNA is below the resolution of light level autoradiography or that the isoformspecific mRNA in these dendrites differs from that expressed in perikarya.

\section{Localization in Cerebellum}

In cerebellar cortex, granule cells expressed $\alpha$ mRNA (Fig. 8B) as well as polypeptide, as judged by immunofluorescence (Fig. 8C) and immunoperoxidase staining (Siegel et al., 1984). Because astrocytic velate processes envelop granule cell bodies and since the so-

Fig. 8. Localization of $\alpha$-subunit mRNA and polypeptide in mouse cerebellum. A: The Purkinje cell layer (PC) exhibited a strong hybridization signal with the ${ }^{35} \mathrm{~S}$-riboprobe. Focal accumulations of autoradiographic grains were present in the molecular layer (ML) and the granular layer (GC). White matter (asterisk) was unlabeled. B: Intense labeling with the ${ }^{35} \mathrm{~S}$-riboprobe was seen in perikarya of Purkinje cells $(\mathrm{P})$, basket cells (arrow), stellate cells (curved arrowhead), and granule cells (small arrowheads). Glomeruli (G) were poorly labeled. C: Immunostaining of $\alpha$-subunit with $31 \mathrm{~B}$ antiserum was pronounced in basket regions (asterisks) and glomeruli (G) and outlined granule cell (arrows) and basket/stellate cell (curved arrowhead) soma. Purkinje cell bodies (P) and their proximal dendrites (straight arrowheads) appeared unreactive. The neuropil of the overlying molecular layer was diffusely reactive. A: autoradiogram, darkfield. $\times 75$. B: autoradiogram, phase contast. $\times 625$. C: epifluorescence. $\times 375$. 
mal cytoplasm in these cells is restricted to a thin perinuclear ring, some of the $\alpha$-mRNA and $\alpha$-polypeptide might be associated with astrocytic elements. Immunoperoxidase studies at the electron microscope level with 31B have resolved $\alpha$-subunit at the granule cell somal plasma membrane and in axonal and astrocytic velate processes in the granular layer (unpublished observations).

Basket cells also expressed $\alpha$-mRNA (Fig. 8B), and basket regions composed of basket cell axonal terminals juxtaposed to the axon hillocks and initial axon segments of Purkinje cells were intensely immunoreactive for $\alpha$-subunit (Fig. 8C; Siegel et al., 1984). A recent report (Schneider et al., 1988) described $\alpha 3$-mRNA cerebellar labeling in adult rats as largely restricted to the Purkinje cell layer. Inspection of Figure $3 \mathrm{C}$ in that paper suggests to us that labeling above background with their probe was also present in granular and molecular layers although Purkinje cell labeling was dominant. The current report clearly resolved labeled mRNA in adult mouse cerebellum within stellate, basket, and granule cells as well as abundant signal within Purkinje cell bodies (Fig. 8A,B). Because of the large size of Purkinje cells, their mRNA content appears particularly striking. However, the considerably smaller cytosolic volume of basket, stellate, and, particularly, granule cells, suggests that the distinct hybridization signal resolved in these cells may represent a relatively high degree of $\alpha$-mRNA expression. Since the probe used in this study showed a large reaction with rat $\alpha 1$-cDNA and very little reaction with $\alpha 2$ - and $\alpha 3$-cDNAs on blots, even at low stringency (Fig. 4B), the bulk of labeling in situ is attributed to $\alpha 1$-mRNA. These observations, taken together with the data reported for adult rat cerebellum by Schneider et al. (1988), suggest that multiple $\alpha$-subunit isoform mRNAs (at least, $\alpha 1$ and $\alpha 3$ ) are expressed by some individual CNS cells. If so, the different isoforms might be translated or processed at different times, routed to different locations within the cell, or even combined in hybrid molecular assemblies.

As indicated above, Purkinje cell bodies showed abundant accumulation of $\alpha-m R N A$ (Fig. 8A,B). However, when the same antiserum (31B) that selected the cDNA clone was used, there was no clearly resolvable immunofluorescence localization of $\alpha$-subunit polypeptide to Purkinje cell soma or to proximal portions of dendrites that emerge from these cell bodies (Fig. 8C). The staining that outlines Purkinje cell bodies seen in Figure $8 \mathrm{C}$ and in an earlier immunoperoxidase study (Siegel et al., 1984) appeared on close examination to be primarily related to juxtaposed basket terminals and glial enwrapments, and this interpretation is consistent with immunoelectron microscope studies with this antiserum (unpublished observations). In contrast, granule cells and retinal photoreceptor inner segments and ganglion cells (see above) expressed both $\alpha$-mRNA (Figs. 8B, 7C) and somal plasmalemma polypeptide (Figs. 8C, 7B). It is possible that the bulk of synthesized $\alpha$-subunit in Purkinje cells is transported to and inserted in membranes of distal processes. If $\mathrm{Na}, \mathrm{K}$-ATPase is present in Purkinje somal plasmalemma, it is a different isoform than that detected in granule and retinal ganglion cell perikarya and photoreceptor inner segments.

\section{SUMMARY}

The data from kidney, retinal, and cerebellar localizations suggest close coupling between $\alpha 1$-mRNA accumulation and expression of catalytic subunit protein. In addition, the retinal and cerebellar studies suggest that in some cells, the bulk of polypeptide may accumulate at membranes that are remote from the primary site of translation. Whether isoform-specific differences in the routing to specific membrane domains also exist remains to be determined.

\section{ACKNOWLEDGMENTS}

We thank Catherine Leggieri for assistance in preparation of the manuscript. We gratefully acknowledge the assistance of Dr. Stanley Watson and Sharon Burke in the performance of in situ hybridization procedures. We also thank Dr. Robert Levenson and Dr. Jerry Lingrel for generously providing us with their rat $\alpha$-isoform cDNA clones and Dr. Pamela Raymond and Dr. Robert Erickson for their helpful comments on the manuscript. This research was supported by NIH grants NS15935, 5P60DK20572, and DK27559.

\section{REFERENCES}

Albers RW, Siegel GJ, Stahl WL (1989): Membrane transport. In Siegel GJ, Agranoff BW, Albers RW, Molinoff PB (eds): "Basic Neurochemistry." 4th edition. New York: Raven Press, pp 49-70.

Barnstable C (1987): A molecular view of vertebrate retinal development. Mol Neurobiol 1:9-46.

Bevilacqua A, Erickson RP, Hieber V (1988): Antisense RNA inhibits endogenous gene expression in mouse preimplantation embryos: Lack of double-stranded RNA "melting" activity. Proc Natl Acad Sci USA 85:831-835.

Charlemagne O, Mayoux E, Poyard M, Oliviera P, Geering K (1987): Identification of two isoforms of the catalytic subunit of $\mathrm{Na}, \mathrm{K}$ ATPase in myocytes from adult rat heart. $\mathrm{J}$ Biol Chem 262:8941-8943.

Emanuel JR, Garetz S, Stone L, Levenson R (1987): Differential expression of $\mathrm{Na}, \mathrm{K}$-ATPase $\alpha$ and $\beta$ subunit mRNAs in rat tissues and cell lines. Proc Natl Acad Sci USA 84:9030-9034.

Ernst SA, Palacios JR II, Siegel GJ (1986): Immunocytochemical localization of $\mathrm{Na}+, \mathrm{K}+$-ATPase catalytic polypeptide in mouse choroid plexus. J Histochem Cytochem 34:189-195.

Ernst SA, Schreiber JH (1981): Ultrastructural localization of $\mathrm{Na}, \mathrm{K}-$ ATPase in rat and rabbit kidney medulla. J Cell Biol 91: 803-813. 
Ernst SA (1975): Transport ATPase cytochemistry: Ultrastructural localization of potassium-dependent and potassium-independent phosphatase activities in rat kidney cortex. $J$ Cell Biol 66:586-608

George DG, Barker WC, Hunt LT (1986): The protein identification resource (PIR). Nucleic Acids Res 14:11-15.

Herrera VL, Emanuel JR, Ruiz-Opazo N, Levenson R, Nadal-Girard B (1987): Three differentially expressed $\mathrm{Na}, \mathrm{K}$-ATPase $\alpha$-subunit isoforms: Structural and functional implications. J Cell Biol 105:1855-1865.

Hieber VC, Siegel GJ, Desmond TJ, Liu-Hwa J, Ernst SA (1988): Localization of $\mathrm{Na}, \mathrm{K}-\mathrm{ATPase} \alpha$-subunit mRNA and polypeptide in mouse kidney, cerebellum, and retina. Soc Neurosci Abst 14:1324.

Kashgarian M, Beimesderfer D, Caplan M, Frobush B III (1985): Monoclonal antibody to Na,K-ATPase: Immunocytochemical localization along nephron segments. Kidney Int 28:899-913.

Kawakami K, Ohta T, Nojima H, Nagano K (1986): Primary structure of the $\alpha$-subunit of human $\mathrm{Na}, \mathrm{K}$-ATPase deduced from cDNA sequence. J Biochem 100:389-397.

Kawakami K, Nagano K (1988): The transmembrane segment of the human $\mathrm{Na}, \mathrm{K}$-ATPase $\beta$-subunit acts as the membrane incorporation signal. J Biochem 103:54-60.

Kent RB, Fallows DA, Geissler E, Glaser T, Emanuel JR, Lalley PA, Levenson R, Housman DE (1987): Genes encoding $\alpha$ and $\beta$ subunits of $\mathrm{Na}, \mathrm{K}$-ATPase are located on three different chromosomes in the mouse. Proc Natl Acad Sci USA 84: $5369-5373$.

Laemmli UK (1970): Cleavage of structural proteins during the assembly of the head of bacteriophage T4. Nature 227:680-685.

Lehrach H, Diamond D, Wazney JM, Boedtker H (1977): RNA molecular weight determination by gel electrophoresis under denaturing conditions, a critical reexamination. Biochemistry 16:4743-4751.

Lytton J, Lin JC, Guidotti G (1985): Identification of two molecular forms of $(\mathrm{Na}+, \mathbf{K}+)$-ATPase in rat adipocytes. J Biol Chem 260:1177-1184.

Maniatis T, Fritsch EF, Sambrook J (1982): "Molecular Cloning. A Laboratory Manual." Cold Spring Harbor, New York: Cold Spring Harbor Laboratory.

Matsuda T, Iwata H, Cooper JR (1984): Specific inactivation of $\alpha(+)$ molecular form of $(\mathrm{Na}++\mathrm{K}+)$-ATPase by pyrithiamin. $\mathrm{J}$ Biol Chem 259:3858-3863.

McGrail KM, Sweadner KJ (1986): Immunofluorescent localization of two different $\mathrm{Na}, \mathrm{K}$-ATPases in the rat retina and in identified dissociated retinal cells. J Neurosci 6:1272-1283.

Meinkoth J, Wahl G (1984): Hybridization of nucleic acids immobilized on solid supports. Anal Biochem 138:267-284.

Morohashi M, Kawamura M (1984): Solubilization and purification of Artemia salina $(\mathrm{Na}, \mathrm{K})$-activated ATPase and $\mathrm{NH} 2$-terminal amino acid sequence of its larger subunit. J Biol Chem 259:14928-14934.

Noguchi S, Mishina M, Kawamura M, Numa S (1987): Expression of functional Na,K-ATPase from cloned cDNAs. FEBS Lett 225:27-32.

Ovchinnikov Yu A, Modyanor NN, Broude NE, Petrukhin KE, Grishin AV, Arzamazova NM, Aldanova NA, Monastyrskaya GS, Sverdlov ED (1986): Pig kidney $\mathrm{Na}+, \mathrm{K}+$-ATPase. FEBS Lett 201:237-245.

Sanger F, Nicklen S, Coulson AR (1977): DNA sequencing with chain-terminating inhibitors. Proc Natl Acad Sci USA 74: $5463-5467$.
Schneider JW, Mercer RW, Gilmore-Herbert M, Utset MF, Lai C, Greene A, Benz EJ, Jr. (1988): Tissue specificity, localization in brain, and cell-free translation of mRNA encoding the A3 isoform of Na,K,ATPase. Proc Natl Acad Sci USA 85: $284-288$.

Shull GE, Schwartz A, Lingrel JB (1985): Amino-acid sequence of the catalytic subunit of the $(\mathrm{Na}++\mathrm{K}+)$ ATPase deduced from a complementary DNA. Nature 316:691-695.

Shull GE, Greeb J, Lingrel JB (1986): Molecular cloning of three distinct forms of the $\mathrm{Na}+, \mathrm{K}+$-ATPase $\alpha$-subunit from rat brain. Biochemistry 25:8125-8132.

Shull GE, Lingrel JB (1986): Molecular cloning of the rat stomach $\left(\mathrm{H}^{+}+\mathrm{K}^{+}\right)$-ATPase. J Biol Chem 261:16788-16791.

Shull MM, Lingrel JB (1987): Multiple genes encode the human $\mathrm{Na}+, \mathrm{K}+$-ATPase catalytic subunit. Proc Natl Acad Sci USA 84:4039-4043

Siegel GJ, Desmond T, Ernst SA (1986): Immunoreactivity and ouabain-dependent phosphorylation of $(\mathrm{Na}++\mathrm{K}+)_{\text {-adeno- }}$ sinetriphosphatase catalytic subunit doublets. J Biol Chem 261: $13768-13776$.

Siegel GJ, Holm C, Schreiber JH, Desmond TJ, Ernst SA (1984): Purification of mouse brain $(\mathrm{Na}+, \mathrm{K}+)$-ATPase catalytic unit, characterization of antiserum, and immunocytochemical localization in cerebellum, choroid plexus, and kidney. $\mathrm{J}$ Histochem Cytochem 32:1309-1318

Skou JC (1988): Overview: The Na,K-pump. In Fleischer S, Fleischer B (eds): "Methods in Enzymology," Vol. 156. New York: Academic Press, Inc., pp 1-25.

Specht SC, Sweadner KJ (1984): Two different Na,K-ATPases in the optic nerve: Cells of origin and axonal transport. Proc Natl Acad Sci USA 81:1234-1238.

Stahl WL (1986): The $\mathrm{Na}+, \mathrm{K}+-\mathrm{ATPase}$ of nervous tissue. Neurochem Int 8:449-476.

Strohman RC, Moss PS, Micou-Eastwood J, Spector D, Przybyla A, Paterson B (1977): Messenger RNA for myosin polypeptides: Isolation from single myogenic cell cultures. Cell 10:265-273.

Sverdlov ED, Monastyrskaya GS, Broude NE, Ushkaryov Yu A, Allikmets RL, Melkov AM, Smirnov Yu V, Malyshev IV, Dulobova IE, Petrukhin KE, Grishin AV, Kijatkin NI, Kostina MB, Sverdlov VE, Modyanov NN, Ovchnikov Yu A (1987): The family of human Na,K,ATPase genes. FEBS Lett 217: $275-278$.

Sweadner KJ (1979): Two molecular forms of (Na $++\mathbf{K}+)$-stimulated ATPase in brain. J Biol Chem 254:6060-6067

Towbin H, Staehelin T, Gordon J (1979): Electrophoretic transfer of proteins from polyacrylamide gels to nitrocellulose sheets: Procedure and some applications. Proc Natl Acad Sci USA 76:4350-4354

Watson SJ, Sherman TG, Kelsey JE, Burke S, Akil H (1987): Anatomical localization of mRNA: In situ hybridization of neuropeptide systems. In Valentino KL, Eberwine JH, Barchas JD (eds): "In Situ Hybridization: Applications to Neurobiology." New York: Oxford University Press, Inc., Chap 7, pp 126145 .

Weinstock R, Sweet R, Weiss M, Cedar H, Axel R (1978): Intragenic DNA spacers interrupt the ovalbumin gene. Proc Natl Acad Sci USA 75:1299-1303.

Young RA, Davis RW (1985): Immunoscreening lambda gt 11 recombinant DNA expression libraries. Genet Eng 7:29-41.

Young RM, Lingrel JB (1987): Tissue distribution of mRNAs encoding the $\alpha$-isoforms and $\beta$-subunit of rat $\mathrm{Na}, \mathrm{K}$-ATPase. Biochem Biophys Res Commun 145:52-58. 